\title{
Do Antarctic benthic invertebrates show an extended level of eurybathy?
}

\author{
T. BREY, C. DAHM, M. GORNY, M. KLAGES, M. STILLER, and W.E. ARNTZ \\ Alfred Wegener Institute for Polar and Marine Research, Postfach 120 161, D-27515 Bremerhaven, Germany
}

\begin{abstract}
Depth distribution data were compared for 172 European and 157 Antarctic benthic invertebrate species occurring in the respective shelf areas. Antarctic species showed significantly wider depth ranges in selected families of the groups Bivalvia, Gastropoda, Amphipoda and Decapoda. No differences were found in Polychaeta, Asteroidea and Ophiuroidea, where European species also showed comparatively wide bathymetric ranges. These extended levels of eurybathy in the Antarctic benthos may be interpreted either as an evolutionary adaptation or pre-adaptation to the oscillation of shelf ice extension during the Antarctic glacial-interglacial cycle.
\end{abstract}

Received 2 October 1995, accepted 17 November 1995

Key words: benthic invertebrates, bivalves, gastropods, amphipods, decapods

\section{Introduction}

It seems to be a commonly accepted idea in the scientific community that Antarctic benthic invertebrates exhibit extended levels of eurybathy when compared to their boreal or tropic counterparts. Explicit statements of this kind have been made by Dell (1972) (especially for sponges, corals, polychaetes and molluscs), George (1974) (polar benthos in general), Knox (1977) (polychaetes) and Brandt (1991) (isopods).

Although the literature provides many examples of wide bathyal ranges for Antarctic species, genera and families (see references above), a proper comparison of bathymetric ranges in Antarctic and non-Antarctic species is still missing. Therefore we will test the hypotheses:

$\mathrm{H}_{\mathrm{o}}$ : There is no difference in the extent of eurybathy in Antarctic and non-Antarctic benthic invertebrate species.

$\mathrm{H}_{\mathrm{A}}$ : Antarctic species show wider bathymetric ranges than non-Antarctic species.

\section{Methods}

Many of the comments on Antarctic eurybathy refer to higher taxonomic levels such as genus or family. However, if there is a specifically Antarctic evolutionary development of eurybathy, the comparison should be carried out at the species level, because natural selection and evolution work on species. For this reason we used bathymetric ranges of species as the basic measure. To exclude true deep sea species from the analysis, the minimum condition for any species to be included was its occurrence on the respective shelf.

The comparison should cover the major taxonomic groups of the benthos. In order to minimize bias caused by pooling of different taxa, we aimed at the comparison of Antarctic and non-Antarctic species within families. However, in most cases the number of data was insufficient, and data had to be pooled from several families.

We selected Europe as the area to be compared with Antarctica, because the long history of marine research in this area provides a large set of easily accessible bathymetric data.

From the literature cited in the legend of Table I, we collected bathymetric data referring to 172 European species, i.e. species with their centre of distribution in European waters, and 157 Antarctic species. These species belonged to the groups Bivalvia (five families pooled), Gastropoda (six families pooled), Polychaeta (two families pooled), Amphipoda (family Lysianassidae), Decapoda (five families pooled), Asteroidea (16 families pooled), and Ophiuroidea (eight families pooled). Unfortunately, we could not gather sufficient data for other important groups such as Porifera or Cnidaria.

The depth range data (maximum minus minimum depth recorded) of each species were log-transformed to achieve normal distribution; these data were tested for significant differences between Europe and Antarctica within each of the seven taxonomic groups using analysis of variance.

\section{Results}

We found significantly $(P \leq 0.05)$ wider bathymetric ranges of Antarctic species in the groups Bivalvia, Gastropoda, Amphipoda and Decapoda (Table I). No differences were found in the groups Polychaeta, Asteroidea and Ophiuroidea (Table I). Fig. 1 shows the bathymetric ranges of all species included except those from the groups Bivalvia and Polychaeta.

\section{Discussion}

The results of our study may be biased by some methodical problems. Our plain statistical approach does not allow for 
Table I. Statistical comparison of depth range per species in various taxonomicgroups.

\begin{tabular}{|c|c|c|c|c|c|c|}
\hline \multirow[b]{3}{*}{ Taxon } & \multirow[b]{3}{*}{$\begin{array}{l}\text { Families } \\
\text { included }\end{array}$} & \multicolumn{4}{|c|}{ Depth range per species (m) } & \multirow[b]{3}{*}{$\begin{array}{l}\text { Signif. } \\
\text { diff. }\end{array}$} \\
\hline & & \multicolumn{2}{|c|}{ Europe } & \multicolumn{2}{|c|}{ Antarctica } & \\
\hline & & $\begin{array}{l}\mathrm{N} . \\
\text { species }\end{array}$ & $\begin{array}{l}\text { Geom. } \\
\text { mean }\end{array}$ & $\begin{array}{c}\text { N. } \\
\text { species }\end{array}$ & $\begin{array}{c}\text { Geom. } \\
\text { mean }\end{array}$ & \\
\hline Bivalvia & $\begin{array}{l}\text { Astartidae } \\
\text { Kelliidae } \\
\text { Montautidae } \\
\text { Mytilidae } \\
\text { Nuculanidae }\end{array}$ & 12 & 66 & 12 & 834 & $*$ \\
\hline Gastropoda & $\begin{array}{l}\text { Buccinidae } \\
\text { Fissurellidae } \\
\text { Lamellariidae } \\
\text { Naticidae } \\
\text { Trochidae } \\
\text { Turridae }\end{array}$ & 39 & 212 & 39 & 460 & $*$ \\
\hline Polychaeta & $\begin{array}{l}\text { Aphroditidae } \\
\text { Polynoidae }\end{array}$ & 11 & 618 & 20 & 1099 & - \\
\hline Amphipoda & Lysianassidae & 25 & 244 & 29 & 813 & 中 \\
\hline Decapoda & $\begin{array}{l}\text { Campylonotidae } \\
\text { Crangonidae } \\
\text { Hippolytidae } \\
\text { Lithodidae } \\
\text { Nematocarcinidae }\end{array}$ & 22 & 224 & 10 & 634 & $*$ \\
\hline Asteroidea & $\begin{array}{l}\text { All } 16 \text { families } \\
\text { present in either area }\end{array}$ & 40 & 570 & 28 & 668 & - \\
\hline Ophiuroidea & $\begin{array}{l}\text { All } 8 \text { families } \\
\text { present in either area }\end{array}$ & 23 & 869 & 19 & 867 & - \\
\hline
\end{tabular}

Data sources are Fell 1961, Hartmann 1964, Hartmann-Schröder 1971, Lincoln 1979, Smaldon 1979, Gage et al. 1983, Paterson 1985, Voß 1988, Banard \& Barnard 1990, Hain 1990, Hayward \& Ryland 1990a, 1990b, Sieg \& Wägele 1990, Anntz \& Gorny 1991, Klages 1991, Clark \& Downey 1992, Branch et al. 1993, Stiller 1995, M. Gorny personal communication. *: Significantly different at $P \leq 0.05$.

the fact that individual species are not true statistically independent units because of the phylogenetic links between related species. The rapidly developing new approaches in comparative ecology take these links into account when analysing relations between certain traits and macroevolutionary patterns (e.g. Funk \& Brooks 1990, Stearns 1992). Moreover, the species included in this analysis are not a random selection from the potential candidates for comparison present in either area, but a selection based on the availability of bathymetric data. The pooling of too many, as well as taxonomically or, in an evolutionary sense, too distant families (especially in the groups Asteroidea and Ophiuroidea) may have introduced further bias. Finally, the bathymetric ranges of several Antarctic species included here are likely to be underestimated, because research history has been much shorter than in Europe. Despite these uncertainties, however, we think that the number of data included here makes this first statistical analysis of bathymetric distribution reliable.

In four (Bivalvia, Gastropoda, Amphipoda, Decapoda) of the seven groups investigated bathymetric ranges of Antarctic species are significantly higher than those of European species. Interestingly, the missing difference between Europe

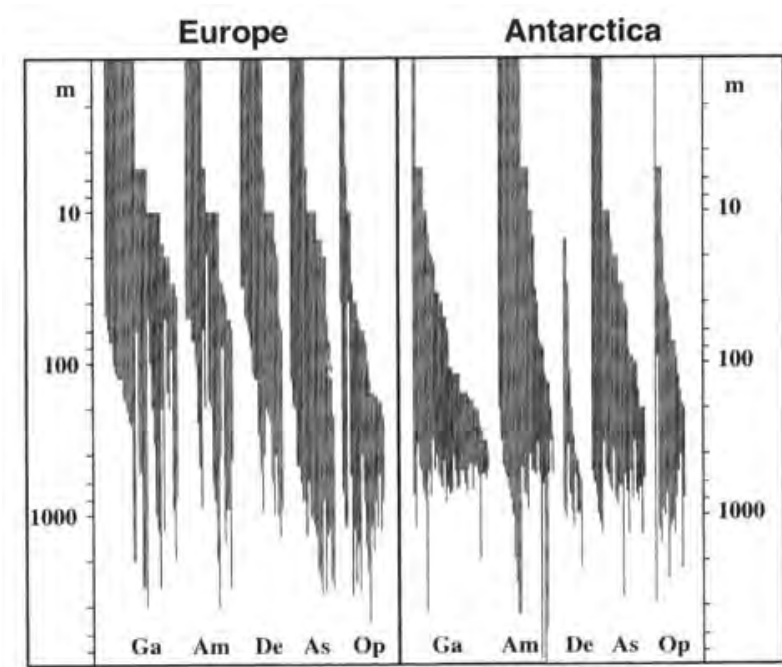

Fig. 1. Depth distribution of shelf inhabiting species of five larger taxonomic groups in Europe and Antarctica. Ga: Gastropoda, Am: Amhipoda, De: Decapoda, As: Asteroidea, Op: Ophiuroidea. One bar represents one species. Note log scale on y-axis. Bivalves and polychaetes are not shown because of too few data. References see Table I.

and Antarctica in the groups Polychaeta, Asteroidea and Ophiuroidea is not due to comparatively small bathymetric ranges within these groups in the Antarctic, but to aboveaverage bathymetric ranges of these groups in Europe (Table I).

Hence, our results indicate that Antarctic benthic invertebrates do indeed show a high level of eurybathy in general, although for some groups this pattern is not restricted to the Southern Ocean.

What may be the reasons for this particular feature of Antarctic benthos? The most convincing hypothesis is related to the palaeoclimatic history of Antarctica (see Clarke \& Crame 1989, 1992, Klages 1991, Galéron et al. 1992).

Sedimentological records (e.g. Anderson et al. 1991, Barrett et al. 1991, Grobe \& Mackensen 1992) indicate that during the Pleistocene periods of large shelf ice extent and low sea water level alternated with periods of small shelf ice extent and high sea water level. During glacial periods the shelf ice grounds on the shelf and may extend beyond the shelf edge. It is possible that this ice impact could cause extinction of the shelf fauna. When the shelf ice retreats during the subsequent interglacial, the defaunated shelf can be re-colonized from other, less affected areas.

There is evidence that this almost regular cycle of shelf ice formation and retreat may have existed for the past two million years. In earlier times glaciation events also occurred at earlier periods, but at less regular intervals (see Quilty 1990, Hodell \& Venz 1992). These glacial-interglacial cycles may have been the driving environmental force towards the evolutionary development of eurybathy in Antarctic benthic invertebrates. In contrast to the north polar sea, Antarctic shelf species cannot retreat from the advancing ice 
Interglacial

Increasing Shelf Ice

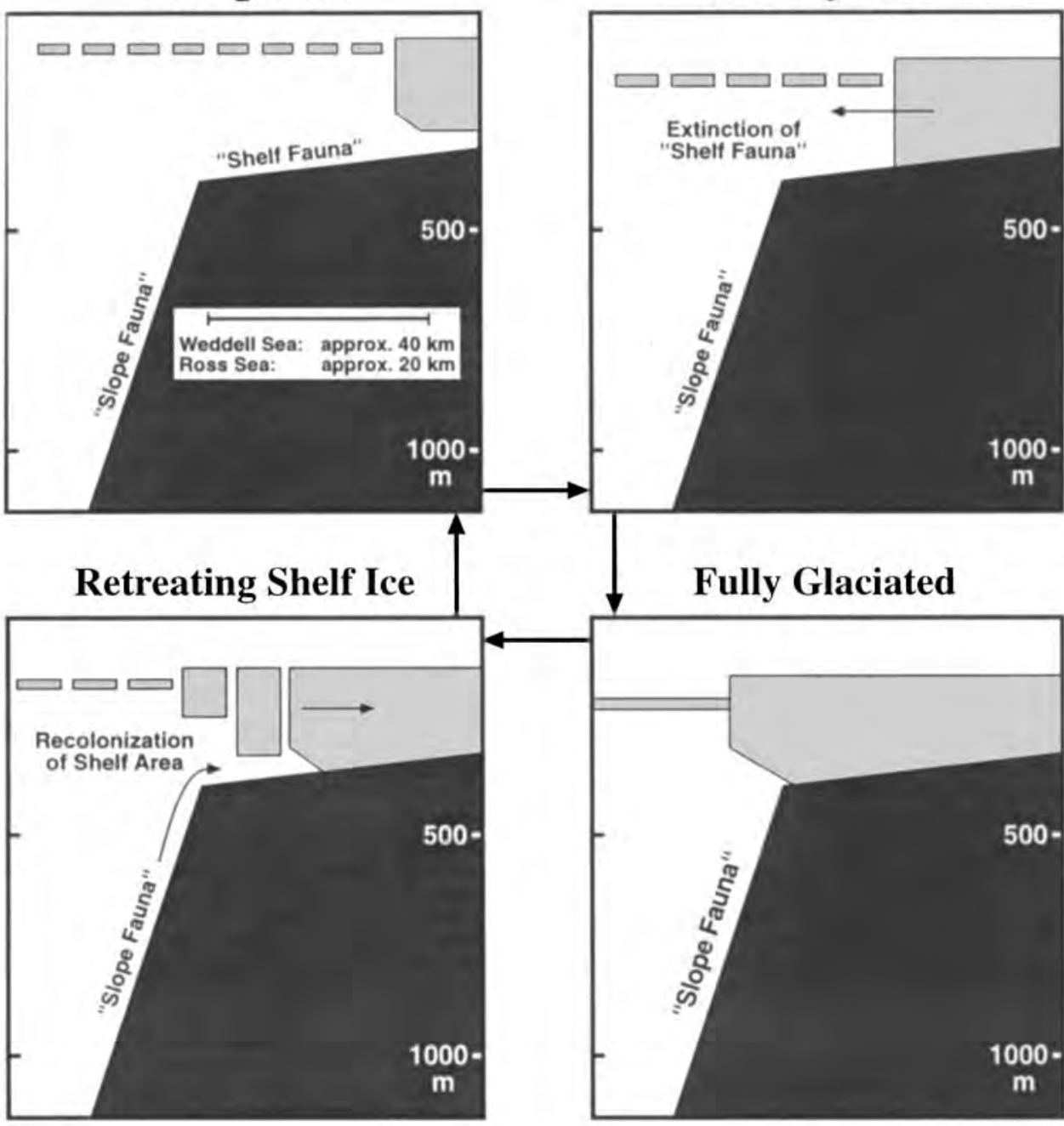

ig. 2. The glacial-interglacial cycle and its impact on the Antarctic shelf fauna.

towards lower latitudes without moving into the deeper waters of the continental slope. Species without this ability are likely to become extinct whilst those with a wider bathymetric range could survive on the slope and quickly recolonize the shelf during interglacial periods (Fig. 2), as indicated by the taxonomic similarities between shelf and slope fauna in Antarctica (e.g. Klages 1991, Galerón et al. 1992).

Our results indicate that in some groups of the Antarctic fauna extended eurybathy may have evolved in the Antarctic, driven by the glacial-interglacial cycles. Other taxa such as Polychaeta, Asteroidea and Ophiuroidea may have inherited extended eurybathy from ancestors common to Antarctic and European species, i.e. as a pre-adaptation to Antarctic conditions, or it may have developed independently in both regions.

\section{Acknowledgements}

We wish to thank Andrew Clarke (British Antarctic Survey) and Paul Tyler (University of Southampton) for their very helpful suggestions which improved this paper substantially. This is AWI Publication No. 981.

\section{References}

Anderson, J.B., Bartek, L.R. \& Thomas, M.A. 1991. Seismic and sedimentological record of glacial events on the Antarctic Peninsula shelf. In Thomson, M.R.A., Crame, J.A \& Thomson, J.W., eds. Geological evolution of Antarctica. Cambridge: Cambridge University Press.

ARNTZ, W.E. \& GoRNY, M. 1991. Shrimp(Decapoda, Natantia) occurrence and distribution in the eastern Weddell Sea, Antarctica. Polar Biology, 11, 169-177.

BARNARD, J.L. \& BARNARD, C.M. 1990. Geographic index to marine Gammaridea (Amphipoda). Washington, DC: Smithsonian Institution, $139 \mathrm{pp}$.

Barrett, P.J., Hambrey, M.J. \& Robinson, P.R. 1991. Cenozoic glacial and tectonic history from CIROS-1, McMurdo Sound. In Thomson, M.R.A., Crame, J.A \& Thomson, J.W., eds. Geological evolution of Antarctica. Cambridge: Cambridge University Press, 722 pp.

Branch, M.L., Jangoux, M., Alvá, V., Massin, C.I. \& Stampanato, S. 1993. The Echinodermata of subantarctic Marion and Prince Edward Islands. South African Journal of Antarctic Research, 23, 37-70.

BrandT, A. 1991. Colonization of the Antarctic shelf by the Isopoda (Crustacea, Malacostraca). Berichte zur Polarforschung, 98, 1-240. [in German]

ClARK, A.M. \& DownEY, M.E. 1992. Starfishes of the Atlantic. London: Chapman \& Hall, 794 pp.

Clarke, A. \& Crame, J.A. 1989. The origin of the Southern Ocean marine fauna. In CRAME, J.A., ed. Origins and evolution of the Antarctic biota. Geological Society Special Publication, 47, 253-268. 
Clarke, A. \& Crame, J.A. 1992. The Southern Ocean benthic fauna and climatic change: a historical perspective. Philosophical Transactions of the Royal Society of London, B339, 299-309.

DAHM, C. 1995. Ecology and population dynamics of Antarctic ophiuroids (Echinodermata). Ph.D. thesis, University of Bremen. [in German].[unpublished]

DELL, R.K. 1972. Antarctic benthos.Advances in Marine Biology, 10, 1-216.

FEIL, H.B. 1961. Ophiuroidea of the Ross Sea. New Zealand Department of Science and Industry Bulletin, 142, 1-79.

Funk, V.A. \& Brooks, D.R. 1990. Phylogenetic systematics as the basis of comparative biology. Smithsonian Contributions to Botany, 73, 1-42.

Gage, J.D., Pearson, M., Clark, A.M., Paterson, G.L.J. \& Tyler, P.A. 1983. Echinoderms of the Rockall Trough and adjacent areas. I. Crinoidea, Asteroidea and Ophiuroidea. Bulletin of the British Museum (Natural History), 45, 263-308.

Galeron, J., Herman, R.L., Arnaud, P.M., Arntz, W.E., Hain, S. \& Klages, M. 1992. Macrofaunal communities on the continental shelf and slope of the southeastern Weddell Sea, Antarctica. Polar Biology, 12, 283-290.

GEORGE, R.Y. 1977. Dissimilar and similar trends in Antarctic and Arctic marine benthos. In Dunbar, M.J., ed. Polar Oceans. Montreal: Arctic Institute of Polar Oceans, 391-408.

GROBE, H. \& MACKENSEN, A. 1992. Late Quatemary climaticcycles as recorded in sediments from the Antarctic continental margin. Antarctic Research Series, 56, 349-376.

HaIN, S. 1990. The benthic seashells (Gastropoda and Bivalvia) of the Weddell Sea, Antarctica. Berichte zur Polarforschung, 70, 1-180. [in German].

HARTMANN, O. 1964. Polychaeta errantia of Antarctica. Antarctic Research Series, 3, 1-131.

Hartmann-SCHröDER, G. 1971. Annelida, Borstenwürmer, Polychaeta. In DAHI, M. \& PEUS, F., eds. Die Tierwelt Deutschlands und der angrenzenden Meeresteile. Jena: G. Fischer, 594 pp.

HAYWARD, P.J. \& RYLAND, J.S., eds. 1990a. The marine fauna of the British Islands and north-west Europe, Vol. 1. Oxford: Clarendon Press, 627 pp.
HAYWARD, P.J. \& RYLAND, J.S., eds. 1990b. The marine fauna of the British Islands and north-west Europe, Vol. 2. Oxford: Clarendon Press, 369 pp. HoDELI, D.A. \& VeNz, K. 1992. Toward a high resolution stable isotopic record of the Southern Ocean during the Pliocene-Pleistocene (4.8 to $0.8 \mathrm{Ma}$ ). Antarctic Research Series, 56, 265-310.

KLAGES, M. 1991. Biologische und populationsdynamische Untersuchungen an ausgewählten Gammariden (Crustacea: Amphipoda) des südostlichen Weddellmeeres, Antarktis. Diss. University Bremen, Germany, 240 pp. [unpublished]

LinCoLN, R.J. 1979. British marine Amphipoda: Gammaridea. London: British Museum, $658 \mathrm{pp}$.

LLANo, G.A.,ed. 1977. Adaptations withinAntarcticecosystems. Proceeding of the Third SCAR Symposium in Antarctic Biology. Washington, DC: Smithsonian Institution, 1252pp.

Paterson, G.L.J. 1985. The deep-sea Ophiuroidea of the North Atlantic Ocean. Bulletin of the British Museum (Natural History), 49, 1-162.

QULTY,P.G. 1990. Significance of evidence for changes in the Antarctic marine environment over the last 5 million years. In KERRY, K.R. \& HEMPEL, G., eds., Antarctic ecosystems: ecological change and conservation. Berlin: Springer-Verlag, 3-8.

SIEG, J. \& WÄGELE, J.-W., eds. 1990. Fauna der Antarktis. Berlin: Parey, $197 \mathrm{pp}$.

SMALDON, G. 1979. British coastal shrimps and prawns. London: Academic Press, $126 \mathrm{pp}$.

StEARNs, S.C. 1992. The evolution oflife histories. Oxford: Oxford University Press, $249 \mathrm{pp}$.

STLLER, M. 1995. Distribution and lifestyle of Aphroditidae und Polynoidae (Polychaeta) in the eastern Weddell Sea and in the LazarevSea (Antarctica) Ph.D.thesis, University Bremen. [in German]. [unpublished]

VoB, J. 1988. Zoogeography and community analysis of macrozoobenthos of the Weddell Sea (Antarctica). Berichte zur Polarforschung, 45, 1-145. [in German]. 